\title{
EL JUEGO DE LA OCA
}

En este número dedicado a Víctor Infantes, que recientemente nos dejó para siempre, el Juego de la Oca, quizás como ningún otro, configura algo más que un simple juego, o con palabras del propio Víctor: "Tras la aparente sencillez de un esparcimiento guiado por el azar de los dados y los sobresaltos de la fortuna, se esconde una enmascarada representación del mundo que nos rodea. Bien es verdad que hay que estar atentos a unos símbolos que a fuerza de ser tan comunes: el puente, el pozo, el tonel, etc., nos parecen carentes de sentido en las casillas de un tablero; dibujos, a la postre, para distraer o para dificultar los avatares de la partida (...). Quizá se trate del juego más antiguo que ha llegado hasta nuestros días, aunque hermano de otros muchos que tienen en común la adivinación, y la destreza en superar dificultades (...)» ([2015]. Lyra mixta. Silva ejemplar de artificios gráfico-literarios, Madrid, Turpin Eds., p. 369). Todo esto, sin duda ninguna, viene muy bien a colación en un contexto como el presente, en que queremos homenajear a alguien de los nuestros, y que -redundancia del destino- nos ha dejado también el mejor estudio verbo-visual (literario / artístico) sobre la Danza Macabra ([1997]. Las danzas de la muerte. Génesis y desarrollo de un género medieval. Siglos XIII-XVII, Ediciones Universidad de Salamanca), un estudio (su tesis doctoral) que, como él mismo nos expresaba, le llegó casi a trastornar, algo comprensible por tratarse justamente de un discurso de antaño difícilmente encajable en nuestra mentalidad contemporánea. Mas sí hay algo claramente real en todo ese discurso: la muerte inexorable, que esta vez, de un zarpazo, nos ha arrebatado al mejor conocedor de la Danza Macabra, lo cual no deja indiferente a cuantos lo conocimos y apreciamos.

Así mismo el Juego de la Oca interpreta simbólicamente nuestro avatar cotidiano. En el contexto de este juego, llama también la atención que la muerte no sea un hecho final, una última etapa o fin del camino, sino un «volver a empezar». En el fondo, los humanos no somos imprescindibles, ya que siempre somos substituidos en nuestras funciones, y el quehacer se renueva y continúa. Puede ser esto también una metáfora de la misma vida 
y trayectoria de la Sociedad Española de Emblemática, vida que está, como la humana, sujeta a toda clase de trabajos, con sus dificultades, gozos y sinsabores, y su régimen siempre en constante y cíclica renovación.

Al igual que en el Juego de la Oca, existen unas reglas, las cuales han podido ir cambiando a lo largo del tiempo. Víctor Infantes indicaba que este juego probablemente se practicaba ya en la Grecia clásica y que a finales del siglo XV se conformó como un tablero xilográfico de 63 casillas «aunque se conservan variantes que no tuvieron éxito de hasta $142 »$, prueba evidente -entendemos- de que todo lo complejo y sofisticado, lo que se aleja de la sencillez, acaba siendo desechado como enmarañado e innecesario. Del mismo modo, la SEE se encuentra en un momento de renovación de sus Estatutos para adaptarlos a los tiempos; renovación que intenta racionalizar el régimen de nuestra convivencia buscando siempre la vía más adecuada, ajustada con sencillez a la tradición específica de nuestro modo de gobernarnos. Así también, las reglas del Juego de la Oca han ido cambiando a través de los tiempos. Veamos cómo eran éstas entre los siglos XVI y XVII, siglos áureos de la Emblemática clásica, diferentes a las reglas que, según recordamos, se seguían en el cartón de los Juegos Reunidos de Geyper, aunque, en el fondo, los cambios no han llegado a ser substanciales:

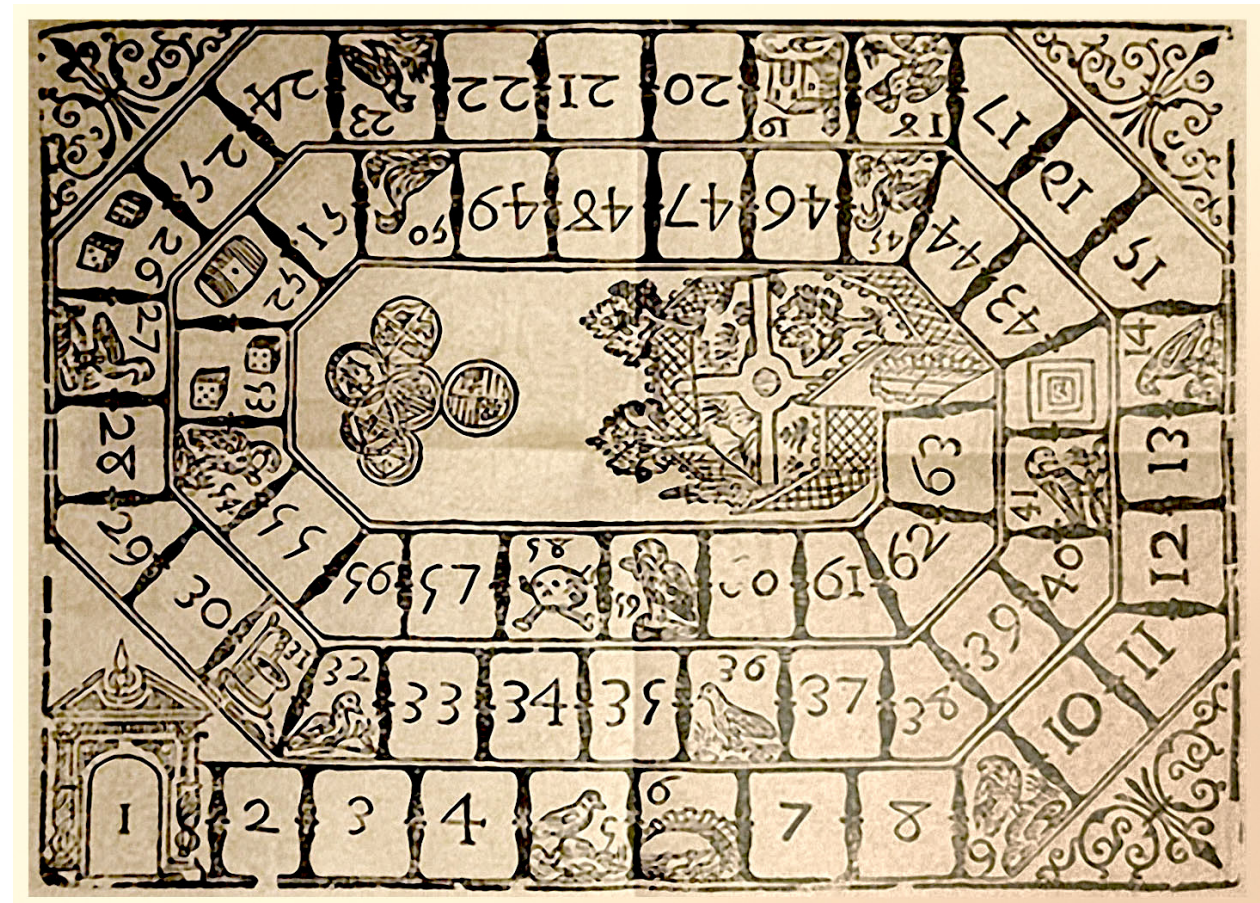


'Al empezar, el que saca tres y seis, se pone al número 26, y si es cuatro y cinco, al número 53. El que da en una oca, vuela hasta no dar en otra. En el 6 paga, y se pasa al 12. En la venta paga, y no juega una vez. En el pozo paga, y no sale hasta que otro le saque. En el laberinto paga, y vuelve al 39. En la torre paga, y no juega tres vezes. En la muerte se vuelve a empezar. Desde el 60 con un dado, volando del 63 atrás, hasta venir justo, y se gana.' A coger los cubos y: suerte (Víctor Infantes, Lyra mixta, ed. cit., pp. 371-372).

En este número 9 de IMAGo hemos tenido que ajustarnos, en cuanto a extensión y número de artículos, a lo acostumbrado, pese a que hubiesen sido incontables las colaboraciones en memoria de Víctor Infantes. Por lo tanto, no ha sido posible sobrepasar los límites exigidos para la evaluación de la calidad de las revistas científicas. Por último, debemos agradecer a la profesora Ana Martínez Pereira la labor de coordinación de este número. 
